\title{
Dual labelling of circulating CD8 cells in patients with multiple sclerosis
}

\author{
P J HUGHES, P F KIRK, D A S COMPSTON \\ From the Section of Neurology, University of Wales College of Medicine, Heath Park, Cardiff, UK
}

SUMMARY Peripheral blood T cell phenotypes have been analysed in serial samples from patients with multiple sclerosis, their unaffected relatives and controls using a panel of antibodies chosen to distinguish $\mathrm{T}$ suppressor and activated suppressor cells from other CD8 lymphocytes. Overall, the percentage of Leu $2 \mathrm{a}$ cells correlated with alterations in the Leu 2a/15 suppressor sub-population $(\mathrm{r}=0.79, \mathrm{p}<0.001)$. Fewer circulating Leu $2 \mathrm{a}$ and Leu $2 \mathrm{a} / 15$ positive cells were identified in multiple sclerosis patients than unaffected individuals but there was no alteration in percentage of activated (Leu 2a/DR) CD8 cells. These findings suggest that the fluctuations in CD8 cells, characteristic of patients with multiple sclerosis, are due to alterations in T suppressor phenotype; this may then lower the threshold for activation of other $\mathrm{T}$ cell subpopulations.

Two major populations of circulating $\mathrm{T}$ lymphocytes can be defined serologically. Leu 2a, OKT5 and OKT8 identify the suppressor/cytotoxic (CD8) subset and Leu $3 \mathrm{a}, 3 \mathrm{~b}$ and OKT4 the helper/inducer (CD4) subpopulation. A reduction in number or percentage of OKT 5 and T8 cells has been reported ${ }^{1-7}$ but also disclaimed $^{8-11}$ in patients with multiple sclerosis, although results are more consistent using the Leu 2a antibody..$^{12-14}$

Monoclonal antibodies can be used singly or in combination to identify less heterogenous lymphocyte populations including those characterised by the presence of activation markers expressed transiently during $\mathrm{T}$ cell maturation. ${ }^{15-19}$ Within the CD8 subset, suppressor and cytotoxic cells can be distinguished using Leu $2 \mathrm{a}$ and Leu 15 in combination ${ }^{15}$ and activated CD8 cells may be identified by dual labelling with Leu $2 \mathrm{a}$ and anti-DR. ${ }^{16}$

Suppressor inducer (CD4: OKT4/2H4 positive) lymphocytes which in turn stimulate the suppressor (CD8: Leu 2a/15) subpopulation are reduced in patients with chronic progressive multiple sclerosis. ${ }^{17}$ Impaired $\mathrm{T}$ suppressor function correlates with the OKT4/2H4 but not CD8 phenotype ${ }^{1720-23}$; the likely explanations are first that the CD8 antigen is present on cells other than $T$ suppressor lymphocytes, and secondly that non-specific functional suppressor

Address for reprint requests: Professor D A S Compston, Dept of Medicine, University of Wales College of Medicine, Heath Park, Cardiff CF4 4XN UK

Received 27 October 1987 and in revised form 21 June 1988. Accepted 26 August 1988 assays involve a complex interaction of $\mathrm{B}, \mathrm{T}$ helper and suppressor cell responses to plant mitogens.

There is an increase in $T$ cells expressing early and late activation markers in patients with multiple sclerosis; ${ }^{1924-28}$ some of these antigens are present on activated $T$ helper/inducer (CD4) and cytotoxic/suppressor (CD8) lymphocytes whereas the expression of others is not confined to $\mathrm{T}$ lymphocytes at all.

In order to define the contribution of fluctuations in suppressor cells to serial changes in the CD8 phenotype, samples cryopreserved at the time of previously reported studies of lymphocyte subpopulations within families ${ }^{29}$ have now been investigated by dual monoclonal antibody labelling. Functional and phenotypic correlations have not been made in aliquots of the same samples.

\section{Methods}

Unfractionated lymphocytes were obtained from up to 12 samples of peripheral blood taken between 7.30-10.30 am at weekly intervals from each of six patients with clinically definite multiple sclerosis, five cohabitant relatives (four spouses and one sister), four non-cohabitant siblings and seven unrelated normal controls. OKT4 and T8 cells were previously enumerated using fresh lymphocytes by indirect immunofluorescence. ${ }^{29}$ At that time $20 \times 10^{6}$ lymphocytes in $250 \mu \mathrm{l}$ of foetal calf serum were mixed on ice in roundbottomed freezing tubes with $250 \mu \mathrm{l}$ of $20 \%$ dimethylsulfoxide (DMSO), kept at $-70^{\circ} \mathrm{C}$ for up to 16 hours and then stored in liquid nitrogen for up to 9 months.

Stored cells were subsequently thawed rapidly, transferred to $20 \mathrm{ml}$ of medium at $20^{\circ} \mathrm{C}$ for 20 minutes and resuspended at a concentration of $20 \times 10^{6}$ per $\mathrm{ml}$. Cell viability was 
Table 1 Mean lymphocyte subpopulation percentages in multiple sclerosis patients, their unaffected relatives and controls

\begin{tabular}{|c|c|c|c|c|c|c|}
\hline & $T 8$ & Leu $2 a$ & Leu $2 a / 15$ & Leu $2 a / D R$ & $T 4$ & Leu $3 a / 3 b$ \\
\hline $\begin{array}{l}\text { Multiple sclerosis patients } \\
n=6 \text { ) }\end{array}$ & $13 \cdot 7+2 \cdot 6(52)$ & $12 \cdot 7+4 \cdot 3(34)$ & $4 \cdot 9+2 \cdot 5(34)$ & $5(32)$ & $6 \cdot 3(51)$ & $8(35)$ \\
\hline $\begin{array}{l}\text { Cohabitants }(n=5) \\
\text { Non-cohabitants } \quad(n=4) \\
\text { Controls }(n=7)\end{array}$ & $\begin{array}{l}15 \cdot 7+1 \cdot 1(45) \\
17 \cdot 0+3 \cdot 2(28) \\
19 \cdot 1+6 \cdot 8(62)\end{array}$ & $\begin{array}{l}15 \cdot 9+3 \cdot 4(39) \\
18 \cdot 1+11 \cdot 4(25) \\
22 \cdot 4+11 \cdot 1(49)\end{array}$ & $\begin{array}{l}7 \cdot 9+4 \cdot 4(37) \\
9 \cdot 1+7 \cdot 9(25) \\
7 \cdot 2+4 \cdot 4(46)\end{array}$ & $\begin{array}{l}2 \cdot 4+0 \cdot 6(37) \\
2 \cdot 1+1 \cdot 2(25) \\
2 \cdot 1+1 \cdot 8(48)\end{array}$ & $\begin{array}{l}33 \cdot 5+7 \cdot 7^{*}(45) \\
33 \cdot 5+8 \cdot 0 \dagger(28) \\
35 \cdot 9+5 \cdot 1(62)\end{array}$ & $\begin{array}{l}22 \cdot 9+5 \cdot 6 *(40) \\
20 \cdot 5+6 \cdot 6+(24) \\
29 \cdot 4+9 \cdot 0(47)\end{array}$ \\
\hline
\end{tabular}

$*+=p<0.05$.

(number of observations).

usually $>80 \%$ but the number of cells recovered from a few samples was inadequate for further investigation.

Aliquots containing $1 \times 10^{6}$ cells in $50 \mu \mathrm{l}$ of medium were incubated with $50 \mu$ l of Leu $2 a$ or Leu $3 a / 3 b$ (fluorescein labelled; diluted 1:20) and with either $50 \mu \mathrm{l}$ of Leu 15 or antiDR (phycoerythrin labelled; diluted 1:5 and 1:20 respectively) at $20^{\circ} \mathrm{C}$ for 6 minutes. After further washing, 500 cells were counted on the basis of their characteristic light scatter profiles by flow cytometry on a Becton Dickinson FACS 440 .

\section{Statistics}

Results are expressed as a mean and standard deviation; differences between mean values for all observations from each individual within the four groups were compared by Student's $t$ test based on the number of individuals, not observations. Coefficients of correlation between mean values for the different lymphocyte subpopulations were calculated from each participant, irrespective of clinical status.
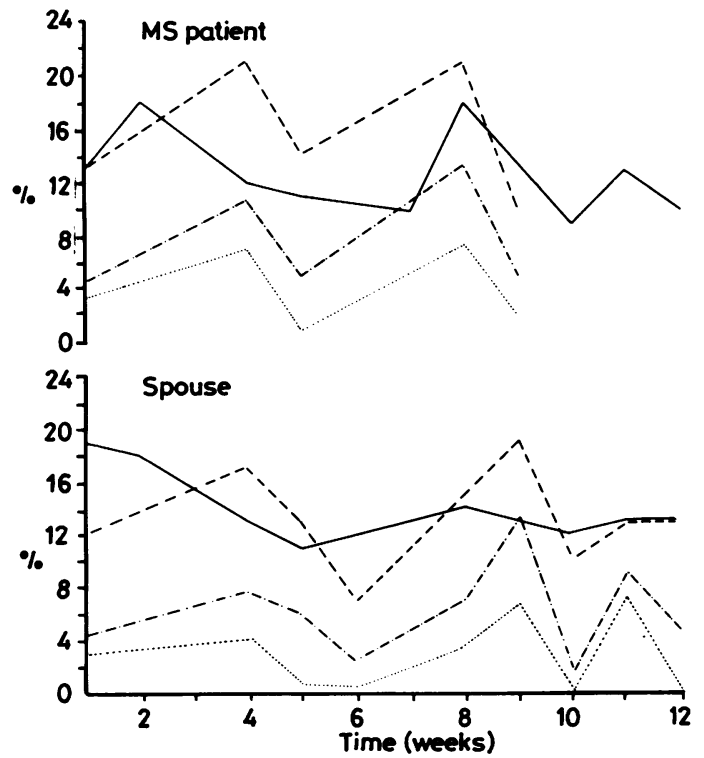

Fig Serial measurements of circulating CD8 (OKT8 [-]) or Leu 2a [- - - ]), suppressor (Leu 2a/15 [ - . . . . . . ) and activated suppressor (Leu $2 a / a n t i D R[\ldots .]$.$) positive cells in serial samples taken$ over 12 weeks from one patient with clinically definite multiple sclerosis and his unaffected wife.

\section{Results}

Our previously reported results demonstrated a reduction in mean percentage of OKT8 cells in multiple sclerosis patients and cohabitant relatives, but not in non-cohabitant siblings or unrelated controls. ${ }^{29}$

In the present study the percentage of cryopreserved Leu $2 \mathrm{a}$ cells was also reduced in samples from six multiple sclerosis patients and five cohabitant relatives compared with four non-cohabitants and seven controls (table). This reduction in CD8 lymphocytes, defined either by OKT8 or Leu 2a was associated with lower percentages of Leu $2 a / 15$ positive cells in multiple sclerosis patients than cohabitants, non-cohabitants or controls. The Leu $2 a / D R$ subpopulation did not differ between groups. Leu $3 a / 3 b$ identified a lower percentage of circulating CD4 cells than OKT4. This difference was significant in cohabitant and non-cohabitant relatives but the $\mathrm{T} 4$ or Leu $3 a / 3 b$ phenotype did not differ between groups.

Using all results available from each participant, there was a strong correlation between Leu $2 \mathrm{a}$ phenotype and OKT8 positive cells $(r=0.87: p<0.001)$; each also correlated with Leu $2 a / 15$ positive cells $(r=0.79: p<0.001$ and $r=0.63: p<0.01$ respectively). The percentage of Leu $3 \mathrm{a} / 3 \mathrm{~b}$ cells correlated with OKT4 phenotype $(r=0.64, p<0.01)$. It may be statistically invalid to treat every sample from each individual separately since there is an a priori expectation of one abnormal result following another. However, a significant correlation between Leu $2 a$ and OKT8 positive cells, and between Leu $2 \mathrm{a}$ and Leu $2 \mathrm{a} /$ 15 phenotype, remained when only the first paired values from each individual were compared $(r=0.73$ : $p<0.001$ and $r=0.47: p<0.05$, respectively); conversely there was no correlation between either Leu $2 a$ or OKT8 and the percentage of Leu 2a/DR positive cells $(r=0.06: p$ NS, and $r=0 \cdot 13$ : $p$ NS respectively).

Despite these correlations, OKT8 Leu 2a Leu 2a/15 and Leu $2 a / D R$ positive cell percentages varied independently in serial studies of normal individuals and with only a small number of participants, it was not possible to define normal ranges. Nevertheless the pattern of changes observed in serial observations of patients and their relatives was consistent with the 
conclusion that changes in Leu $2 \mathrm{a}$ cells can be attributed mainly to an alteration in the Leu $2 a / 15$ subpopulation. Representative results are illustrated in one patient and his wife (fig). In both, periodic fluctuations in OKT8 cells were unrelated to changes in the Leu 2a population: conversely, variations in Leu 2a phenotype were associated with transient alterations in Leu $2 \mathrm{a} / 15$ and Leu/DR cells. In the remaining four families, involving five patients and eight relatives (not shown in figures), Leu 2a and OKT8 cell percentages also varied independently whereas in each individual the periodic alterations in Leu 2a cells were usually matched by fluctuations in percentage of Leu $2 \mathrm{a} / 15$ lymphocytes. This trend was less noticeable when comparing Leu $2 \mathrm{a}$ and Leu $2 \mathrm{a} / \mathrm{DR}$ cells.

\section{Discussion}

In the present study we have shown that the reduction in circulating Leu $2 \mathrm{a}$ cells characteristic of patients with multiple sclerosis correlates with fluctuations in the Leu $2 \mathrm{a} / 15$ suppressor cell subset. The study was not designed to reconfirm the observation that circulating CD8 cells are reduced in patients with chronic progressive multiple sclerosis compared with clinically stable cases or unaffected controls. We found that fewer CD8 cells stained with Leu 2a than OKT8 during serial observations in $4 / 6$ patients with multiple sclerosis. It is unlikely that this finding resulted from the use of cryopreserved and fresh cells respectively since Leu 2a and OKT8 identified a similar proportion of cells in samples of peripheral blood from normal controls, which had been handled identically. However, it is possible that the Leu $2 \mathrm{a}$ epitope on lymphocytes from multiple sclerosis patients may be especially vulnerable to freezing. Since there is a poor correlation between results obtained using these two antibodies, the possibility arises that Leu $2 \mathrm{a}$ and OKT8 recognise different components of the heterogenous CD8 cell population; in the investigation of patients with multiple sclerosis the term CD8 should therefore be supplemented by information on the source of antibody used for analysis.

There was a trend towards finding fewer CD8 cells in cohabitant than non-cohabitant relatives of multiple sclerosis patients or unrelated controls using Leu $2 \mathrm{a}$ and OKT 8 but this was not matched by alterations in mean numbers of Leu $2 a / 15$ lymphocytes in these unaffected individuals. This discrepancy between CD8 and suppressor (Leu 2a/15) phenotype is consistent with our demonstration, using mitogen stimulation assays, that T-B cell function is impaired in patients but neither group of unaffected relatives. ${ }^{23} \mathrm{~T} 4, \mathrm{~T} 8$, Leu 2a and Leu 7 positive cells all contribute to $T$ suppressor activity in mitogen stimulation assays ${ }^{21} 22$ but we have not directly correlated phenotype and function in samples from patients with multiple sclerosis or their relatives.

There was no difference in percentage of activated CD8 cells between groups and no pattern to the fluctuations observed in this subpopulation during serial studies of affected individuals or their relatives. Activated $\mathrm{T}$ cells express interleukin 2 receptors (Tac positive) and other early antigens (4/F2, insulin and transferrin receptors) within 48 hours; class 2 (DR) antigen is expressed within a few days whereas Tal, TS2/7 and MLR-1, -2, -3 and -4 appear after several days or weeks. There is an increase in the proportion of lymphocytes expressing the Tac, or interleukin 2 receptor, early activation marker ${ }^{25-27}$ in multiple sclerosis patients but this does not correlate with disease activity and the findings have not consistently been reported, ${ }^{1924}$ an increased percentage of cells bearing the late activation markers Ta1, TS2/7 and MLR-2 has also been demonstrated. ${ }^{181924}$ These markers do not distinguish CD8 from CD4 cells, but our findings suggest that any increase in total activated $\mathrm{T}$ cells, which we did not enumerate in this study, does not involve the CD8 sub-population.

Although it is premature to base firm conclusions about $\mathrm{T}$ cell functions, and hypotheses for the pathogenesis of multiple sclerosis, on changes in phenotype using presently available panels of monoclonal antibodies directed against stable or transiently expressed cell surface markers, the findings are consis-o tent with a defect in $\mathrm{T}$ suppressor cell activity, which may lower the threshold for activation of other T cello subpopulations. The presence of non-specifically activated circulating $T$ cells might then initiate damage to endothelial cells and the blood brain barrier, leading to inflammatory cell infiltration of the central nervous system..$^{31}$

\section{References}

1 Reinherz EL. Weiner HL, Hauser SL, Cohen JA, Distaso JA, Schlossman SF. Loss of suppressor $\mathrm{T}$ cells in active multiple sclerosis. $N$ Eng J Med 1980;303:124-9.

2 Bach M-A, Tournier E, Phan-Dinh-Tuy F, Chatenoud L, Bach J$\mathrm{F}$. Deficit of suppressor $\mathrm{T}$ cells in active multiple sclerosis. Lancet 1980,ii: 1221-3.

3 Compston DAS. Lymphocyte subpopulations in patients with multiple sclerosis. J Neurol Neurosurg Psychiatry 1983:46: 105-14.

4 Hauser SL, Reinherz EL, Hoban CJ, Schlossman SF, Weiner HL. Immunoregulatory T-cells and lymphocytotoxic antibodies in active multiple sclerosis: weekly analysis over a six month period. Ann Neurol 1983;13:418-25.

5 Kastrukoff LF, Paty DW. A serial study of peripheral blood T lymphocyte subsets in relapsing-remitting multiple sclerosis. Ann Neurol 1984;15:250-6.

6 Kuroda Y, Shibasaki H. Peripheral blood and CSF T cell subsets in Japanese multiple sclerosis patients. Neurology 1985;35: 270-3

7 Zaffaroni M, Caputo D, Ghezzi A, Cazzullo CL. T cell subsets in multiple sclerosis: relationships between peripheral blood and 
cerebrospinal fluid. Acta Neurol Scand 1985;71:242-8.

8 Cashman N, Martin C, Eisenbaum J-F, Degos J-D. Monoclonal antibody-defined immunoregulatory cells in multiple sclerosis cerebrospinal fluid. J Clin Invest 1982;70:387-92.

9 Rice GPA, Finney D, Braheny SL, Knobler RL, Sipe JC, Oldstone MBA. Disease activity markers in multiple sclerosis. Another look at suppressor cells defined by monoclonal antibodies OKT4, OKT5 and OKT8. J Neuroimmunol 1984;6:75-84.

10 Mingioli ES, McFarlin DE. Leucocyte surface antigens in patients with multiple sclerosis. J Neuroimmunol 1984;6:131-9.

11 Albala MM, Davignon D, Fast LD, Clark DD. Normal T cell subsets and lymphocyte activity in multiple sclerosis. Clin Exp Immunol 1985;61:542-7.

12 Paty DW, Kastrukoff L, Morgan N, Hiob L. Suppressor Tlymphocytes in multiple sclerosis: analysis of patients with acute relapsing and chronic progressive disease. Ann Neurol 1983;14:445-9.

13 Steck AJ, de Flaugergues J-C. Local and systemic immune response in multiple sclerosis: analysis of CSF inflammatory changes and peripheral blood $\mathrm{T}$ cell subsets. $J$ Neurol 1984;231:126-9.

14 Thompson AJ, Brazil J, Martin EA, Hutchinson M, Whelan CA, Feighery $C$. Suppressor $T$ cell changes in active multiple sclerosis: analysis with three different monoclonal antibodies. $J$ Neurol Neurosurg Psychiatry 1985;48:1062-4.

15 Landay A, Gartland GL, Clement LT. Characterisation of a phenotypically distinct subpopulation of Leu $2+$ cells that suppress T-cell proliferative responses. J Immunol 1983; 131:2757-62.

16 Gatenby PA, Kotzin BL, Kansas GS, Engleman EG. Immunoglobulin secretion in the human autologous mixed leucocyte reaction. Definition of a suppressor-amplifier circuit using monoclonal antibodies. J Exp Med 1982;156:55-67.

17 Morimoto C, Hafler DA, Weiner HL, et al. Selective loss of the suppressor-inducer $\mathrm{T}$ cell subset in progressive multiple sclerosis. N Eng J Med 1987;316:67-72.

18 Hafler DA, Fox DA, Benjamin D, Weiner HL. Antigen reactive memory T cells are defined by Tal. J Immnunol 1986;137: 414-18.

19 Golaz J, Steck A, Moretta L. Activated T lymphocytes in patients with multiple sclerosis. Neurology 1983;33:1371-3.

20 Tjernlund U, Cesaro P, Tournier E, Degos J-D, Bach J-F, Bach MA. $T$ cell subsets in multiple sclerosis: a comparative study between cell surface antigens and function. Clin Immunol
Immunopathol 1984;32:185-97.

21 Oger J, Kastrukoff L, O'Gorman M, Paty DW. Progressive multiple sclerosis: abnormal immune functions in vitro and aberrant correlation with enumeration of lymphocyte subpopulations. J Neuroimmunol 1986;12:37-48.

22 Antel JP, Bania MB, Reder A, Cashman N. Activated suppressor cell dysfunction in progressive multiple sclerosis. J Immunol 1986;137:137-41.

23 Hughes PJ, Compston DAS. T suppressor phenotype and function in multiple sclerosis. J Neurol Neurosurg Psychiatry 1988;51: $1187-92$.

24 Hafler DA, Hemler ME, Christenson L, et al. Investigation of in vivo activated $T$ cells in multiple sclerosis and inflammatory central nervous system diseases. Clin Immunol Immunopathol 1985;37:163-71.

25 Hafler DA, Fox DA, Manning ME, Schlossman SF, Reinherz FL, Weiner HL. In vivo activated T lymphocytes in the peripheral blood and cerebrospinal fluid of patients with multiple sclerosis. New Eng J Med 1985;312:1405-11.

26 Bellamy AS, Calder VL, Feldmann M, Davison AN. The distribution of interleukin 2 receptor bearing lymphocytes in multiple sclerosis: evidence for a key role of activated lymphocytes. Clin Exp Immunol 1985;61:248-56.

27 Selmaj K, Plater-Zyberk C, Rockett KA, et al. Multiple sclerosis: increased expression of interleukin-2 receptors on lymphocytes. Neurology 1986;36:1392-5.

28 Tournier-Lasserve E, Lyon Caen O, Roullet E, Bach MA. IL-2 receptor and HLA class II antigens on cerebrospinal fluid cells of patients with multiple sclerosis and other neurological diseases. Clin Exp Immunol 1987;67:581-6.

29 Hughes PJ, Kirk PF, Compston DAS. Suppressor T cells in family members of patients with multiple sclerosis. Brain 1986;109:969-85.

30 Merrill JE, Mohlstrom C, Uittenbogaart C, Kermani-Arab V, Ellison GW, Myers LW. Response to and production of interleukin 2 by peripheral blood and cerebrospinal fluid lymphocytes of patients with multiple sclerosis. J Immunol 1984;133:1931-7.

31 Naparstek Y, Cohen IR, Fuks Z, Vladabsky I. Activated T lymphocytes produce a matrix-degrading heparin sulphate endogylcosidase. Nature 1984;310:241-4.

32 Wekerle H, Linington C, Lassmann H, Meyermann R. Cellular immune reactivity within the CNS. Trends in Neurosciences 1986;9:271-7. 